\title{
Introduction to Marian Chace Foundation Lecture: October 21, 2011
}

\author{
Miriam Roskin Berger, Lecturer
}

\author{
Robyn Flaum Cruz
}

Published online: 14 February 2012

(C) American Dance Therapy Association 2012

It is an honor and a great privilege to introduce, Dr. Mimi Berger, the 2011 Marian Chace Foundation Lecturer. Her many accomplishments and contributions to dance/ movement therapy span the history of the profession and include leadership of the American Dance Therapy Association (ADTA) as its President; leadership and contributions to academic programs in the US and abroad; and recognition, but more importantly, fondness and respect by dance/movement therapists around the world.

Dr. Berger was born and raised in New York City, and 1956 found her at Bard College working on her senior project, an academic study of dance therapy in which she coined the concept and phrase "kinesthetic empathy." This was only the second academic study of dance therapy in the US. After graduation from Bard, Dr. Berger went on to study dance with Alwin Nikolais and Martha Graham, and to perform with the Jean Erdman Theatre of Dance.

She studied with dance therapy pioneers Marian Chace and Irmgaard Bartenieff, and she studied non-verbal communication with Albert Scheflen, Martha Davis, Marion North, Judith Kestenberg, and Warren Lamb. In 1966, she became one of the charter members of the ADTA. Her unique ability to use multiple perspectives has allowed her to focus her work on both the art and science of the discipline, and to blend them in education and promoting the work of dance/movement therapists specifically, and of creative arts therapist in general.

In 1970 she began a 20 year stint as Director of Creative Arts Therapies at Bronx Psychiatric Center. Well before we used the term, she supported diversity in her recruiting practices at Bronx Psychiatric Center. The Creative Arts Therapies Department-more than any other department in the hospital-always reflected those efforts during her tenure as Director. In addition, I want to note that the diversity in that department would be considered outstanding by today's standards.

R. F. Cruz ( $₫)$

Lesley University, 1718 Anderson Pl. SE, Albuquerque, NM 87108, USA

e-mail: robyncruz@comcast.net; movingtheself@gmail.com 
In formal and in informal ways, Dr. Berger worked tirelessly to connect and support the creative arts therapies staff and to make sure that all employees in the hospital had not only a firm understanding of the arts therapies, but had an experience of the arts therapies as part of their new employee orientation. As part of her work in the Bronx, Dr. Berger was instrumental as a Co-Chairperson in generating the first CAT week that was officially established in New York City in 1974.

In 1975, Dr. Berger began teaching at New York University (NYU) in the Master's Program in Dance Therapy. Over her many years of association with the program, she collaborated with colleagues at NYU to recruit students from diverse backgrounds, ethnicities, and cultures and to deliver a curriculum that would serve students as well as professionals. I first met Dr. Berger at NYU in 1979 and I credit her with both welcoming me to, and keeping me in the profession of dance therapy. I was struck with her professionalism, her warmth and graciousness, and her style. I would be so remiss to celebrate Dr. Berger's achievements without mentioning her style! My classmate, Tricia Capello and I will never forget how Dr. Berger walked into the dance studio where our first class with her took place wearing a pencil skirt that fell to just above the knee and the most fabulous stiletto pumps we had ever seen. We knew right away that we had much to learn.

From 1993 to 2003 Dr. Berger was the Director of the Dance Education Program at NYU and she welcomed this opportunity to reconnect with the roots of dance/ movement therapy and to connect with dance educators. She served for many years on the editorial board of the Journal of Dance Education. As 2006 ADTA Conference Chairperson, I remember well that Dr. Berger was instrumental in connecting the ADTA to the National Dance Education Organization (NDEO) for our first successful collaborative conference in 2006. And here we are again this year connecting and collaborating with the NDEO, appreciating the richness that dance and dance education have to offer to dance/movement therapy. Her educational influence is far from over. She is currently the Director of the Dance Therapy Program at the Harkness Dance Center of the 92nd Street Y in New York City, where she has just initiated a new Alternate Route Dance/Movement Therapy Training Program.

Over the years, Dr. Berger helped establish dance/movement therapy training programs in the Czech Republic, the Netherlands, and Sweden, and has also taught dance/movement therapy and the Movement Psychodiagnostic Inventory in France, Germany, Greece, Korea, Norway, Poland, Russia, Slovenia, and Taiwan. She was a keynote speaker at the International Congress of Dance Therapy in Berlin in 1994, also at the Conference on Dance Education in Israel in 2004, and at the Expressive Arts Therapy Congress in Prague in 2010. Dr. Berger was inducted into the Dance Library of Israel Hall of Fame in 2005, and she received the Marian Chace Award for fostering the international growth of dance/movement therapy in 2002.

She conceived the International Panel 17 years ago and she has continued to chair and organize it annually at the ADTA Conference. Along the way, Dr. Berger served the ADTA in other ways, such as supporting a relationship with Human Sciences Press to publish the American Journal of Dance Therapy, a relationship that remains today, although Human Sciences has changed its name. She has served the profession in other interesting ways, such as working a contact with Mickey Hart 
of the Grateful Dead during planning stages of a special Congressional Hearing on DMT and disabilities.

Dr. Berger was honored with the ADTA Lifetime Achievement Award in 2007 and the Charles Kellogg Award in Arts and Letters from Bard College in 2009. Those of you who her, know that I have just touched the tip of the iceberg with naming some of her accomplishments today. But I want to mention an area of her work that has rarely been celebrated publicly.

Dr. Berger's gifts as a mentor have shaped many careers in dance/movement therapy, and the other creative arts therapies, including mine. Always available for consultation, for advice, for letters of recommendation that knock administrator's socks off - she gives freely of herself and her expertise. This generous and ongoing support of her former students throughout their dance/movement therapy careers distinguishes her among educators. It tells the true story of her dedication not just to the field, but also to the individuals who make up this wonderful global profession.

Similar to others here with us today, and around the world, Dr. Berger was first my teacher and then my mentor, and now my dedicated colleague and close friend. It is with great gratitude for all of her accomplishments and qualities - that I present to you-the 2011 Marian Chace Foundation Lecturer, Dr. Miriam Roskin Berger.

\section{Author Biography}

\section{Robyn Flaum Cruz, Ph.D., BC-DMT, LPC}

Robyn Flaum Cruz is Associate Professor, Lesley University Expressive Therapies Ph.D. Program; Past President, ADTA; Editor-in-Chief of The Arts in Psychotherapy; and Contributor and Co-Editor of Dance/Movement Therapists in Action: A Working Guide to Research Options (Charles C. Thomas Publishers) soon to be released in a second edition. She is also Editor of Feders' Art and Science of Evaluation in the Arts Therapies, (2nd ed.), to be released in 2012. 